Supplement of Adv. Sci. Res., 14, 241-245, 2017

https://doi.org/10.5194/asr-14-241-2017-supplement

(c) Author(s) 2017. This work is distributed under

the Creative Commons Attribution 3.0 License.

(c) (1)

Supplement of

\section{Communicating climate change adaptation information using web-based platforms}

\section{Eleni Karali and Kati Mattern}

Correspondence to: Eleni Karali (ekarali8@gmail.com)

The copyright of individual parts of the supplement might differ from the CC BY 3.0 License.
Advances in Science \& Research

Open Access Proceedings 
Supplement Table S1: Overview of examined adaptation platforms

\begin{tabular}{|c|c|c|c|}
\hline $\begin{array}{l}\text { Geographical } \\
\text { scope }\end{array}$ & Adaptation platform & Year of launch & Background information \\
\hline Austria & $\begin{array}{l}\text { Klimawandelanpassung.at (Austrian } \\
\text { Adaptation Platform) }\end{array}$ & 2009 & $\begin{array}{l}\text { The platform has been operational since } 2009 \text { and then substantially updated } \\
\text { and revised in } 2013 \text {. }\end{array}$ \\
\hline Denmark & $\begin{array}{l}\text { Klimatilpasning.dk (Danish National } \\
\text { Adaptation Platform) }\end{array}$ & 2009 & The platform was launched in 2009 and continuously developed since then. \\
\hline Finland & $\begin{array}{l}\text { Climate Guide (Finnish Adaptation } \\
\text { Platform) }\end{array}$ & 2011 & $\begin{array}{l}\text { The planning process started in } 2009 \text {, while the platform became operational } \\
\text { in } 2011 \text {. }\end{array}$ \\
\hline France & $\begin{array}{l}\text { Observatoire National sur les Effets du } \\
\text { Réchauffement Climatique (ONERC) } \\
\text { (French National Adaptation Platform) }\end{array}$ & 2006 & $\begin{array}{l}\text { ONERC evolved into an adaptation portal in 2006, which was revised in } \\
2009 \text { to support the NAPCC. }\end{array}$ \\
\hline Germany & $\begin{array}{l}\text { KomPass - Climate Impacts and } \\
\text { Adaptation in Germany (German } \\
\text { National Adaptation Platform) }\end{array}$ & 2008 & $\begin{array}{l}\text { The platform was launched in } 2008 \text { as a follow-up of the NAS. The } 2011 \\
\text { NAP required strengthening of the portal, which was then re-launched after } \\
\text { improvements in } 2013 \text {. }\end{array}$ \\
\hline Hungary & $\begin{array}{l}\text { Climate Dialogue Forum (Hungarian } \\
\text { National Adaptation Platform) }\end{array}$ & 2013 & The Climate Dialogue Platform was launched in 2013. \\
\hline Ireland & $\begin{array}{l}\text { Climate Ireland (Irish National } \\
\text { Adaptation Platform) }\end{array}$ & 2015 & $\begin{array}{l}\text { A phased approach was followed for the development of the platform, } \\
\text { starting from its planning in } 2010 \text {, and working since then on the } \\
\text { operationalization of the platform, which was launched in } 2015 \text {. }\end{array}$ \\
\hline Norway & $\begin{array}{l}\text { Klimatilpasning.no (Norwegian Climate } \\
\text { Adaptation Portal) }\end{array}$ & 2009 & $\begin{array}{l}\text { Ministry of Climate \& Environment established an adaptation working } \\
\text { group in 2007, and launched a portal, Klimatilpasning.no, in March } 2009 .\end{array}$ \\
\hline Poland & $\begin{array}{l}\text { KLIMADA Adaptation Platform (The } \\
\text { Polish National Adaptation Platform) }\end{array}$ & 2013 & $\begin{array}{l}\text { The platform was developed as part of the KLIMADA project (2011-2013) } \\
\text { and was launched in October } 2013 \text {. }\end{array}$ \\
\hline Spain & $\begin{array}{l}\text { AdapteCCa.es (Spanish National } \\
\text { Adaptation Platform) }\end{array}$ & 2013 & $\begin{array}{l}\text { The idea of developing a platform originated in } 2010 . \text { The platform was } \\
\text { finally launched in } 2013 \text {. }\end{array}$ \\
\hline Sweden & $\begin{array}{l}\text { Klimatanpassning.se (Swedish Portal for } \\
\text { Climate Change Adaptation) }\end{array}$ & 2007 & $\begin{array}{l}\text { The initial version of the portal was launched in } 2007 \text {. Along with the set-up } \\
\text { of the Swedish National Knowledge Centre for Climate Change Adaptation } \\
\text { in } 2012 \text {, an opportunity was provided to re-launch the platform. }\end{array}$ \\
\hline
\end{tabular}




\begin{tabular}{|c|c|c|c|}
\hline Switzerland & $\begin{array}{l}\text { BAFU Thema Anpassung an den } \\
\text { Klimawandel (Swiss Information } \\
\text { Platform on Adaptation to Climate } \\
\text { Change) }\end{array}$ & 2012 & $\begin{array}{l}\text { The mandate of the Federal Council was communicated in } 2009 . \text { The } \\
\text { process of the platform planning took place in } 2010 \text { and the platform was } \\
\text { completed and launched in March } 2012 \text {. }\end{array}$ \\
\hline The Netherlands & $\begin{array}{l}\text { Dutch Adaptation Knowledge/Spatial } \\
\text { Adaptation Portal }\end{array}$ & 2014 & $\begin{array}{l}\text { The first plans for the development of the platform started in December } \\
\text { 2013, with the platform becoming operational in August } 2014 \text {. }\end{array}$ \\
\hline United Kingdom & $\begin{array}{l}\text { GOV.UK climate change adaptation } \\
\text { pages (including Climate Ready Support } \\
\text { Service by the Environment Agency) }\end{array}$ & 2000 & $\begin{array}{l}\text { The UKCIP platform was launched in } 2000 \text { with continuous improvements } \\
\text { and major updates in } 2003,2008,2010 \text { and } 2013 \text {. The national responsibility } \\
\text { for the platform was transferred to Environment Agency in 2012, and the } \\
\text { GOV.UK launched in April 2013. }\end{array}$ \\
\hline Alpine Region & $\begin{array}{l}\text { Klimaportal Alpenkonvention } \\
\text { Climate Adaptation Platform for the } \\
\text { Alps (CAPA) }\end{array}$ & 2014 & $\begin{array}{l}\text { The conceptual work for the development of the platform started in } 2012 \\
\text { and the platform was launched in 2014. There is an additional portal on the } \\
\text { Alpine Convention website supporting its Action Plan for Climate Change. }\end{array}$ \\
\hline $\begin{array}{l}\text { Baltic Sea } \\
\text { Region }\end{array}$ & Baltic Sea Region (BSR) & 2013 & $\begin{array}{l}\text { The implementation period of the Baltic Window lasted from } 2011 \text { to } 2013 . \\
\text { Baltic Window as part of Climate-ADAPT was launched in } 2013 .\end{array}$ \\
\hline Pyrenees & $\begin{array}{l}\text { Observatoire Pyrénéen du Changement } \\
\text { Climatique; OPCC (Pyrenees Climate } \\
\text { Change Observatory) }\end{array}$ & 2010 & $\begin{array}{l}\text { The transnational platform for the Pyrenees was developed within the } \\
\text { Pyrenees Observatory for Climate Change project 2010-2014. }\end{array}$ \\
\hline $\mathbf{E U}$ & $\begin{array}{l}\text { European Climate Adaptation Platform } \\
\text { (Climate-ADAPT) }\end{array}$ & 2012 & $\begin{array}{l}\text { Identified as an integral component of White Paper, Climate-ADAPT was } \\
\text { launched } 2012 .\end{array}$ \\
\hline
\end{tabular}

(Source: Adapted from EEA, 2015a) 